\title{
A new species of the wild dragon tree, Dracaena (Dracaenaceae) from Gran Canaria and its taxonomic and biogeographic implications
}

\author{
AGUEDO MARRERO ${ }^{1 *}$, RAFAEL S. ALMEIDA ${ }^{2}$ AND \\ MANUEL GONZÁLEZ-MARTÍN ${ }^{3}$ \\ ${ }^{1}$ Jardín Botánico Viera y Clavïjo, Apartado 14 de Tafira Alta, 35017, \\ Las Palmas de Gran Canaria, Canary Islands, Spain \\ ${ }^{2}$ Sección de Geografía (DACT), Universidad de Las Palmas de Gran Canaria, \\ Edificio Humanidades, C/. Pérez del Toro Num. 1, 35003, Las Palmas de Gran Canaria, \\ Canary Islands, Spain \\ ${ }^{3}$ Servicio de Planificación de Recursos Naturales, Viceconsejería de Medio Ambiente, \\ Tafira Baja, 35017, Las Palmas de Gran Canaria, Canary Islands, Spain
}

Received Fanuary 1998; accepted for publication April 1998

The arborescent taxa of Dracaena which form the dragon tree group comprise five species found in Macaronesia, Morocco (D. draco), East Africa (D. ombet, D. schizantha), Arabia (D. serrulata) and the island of Socotra (D. cinnabari). A new species of dragon tree, Dracaena tamaranae A. Marrero, R.S. Almeida \& M. González-Martín, is described from Gran Canaria, Canary Islands. This new species differs from $D$. draco, the only other Dracaena species currently known in Macaronesia, in having a growth form and inflorescence type and leaves more similar to the East African and Arabian species of Dracaena. In contrast, $D$. draco appears to be related to $D$. cinnabari. In this paper, we also present a study of the taxonomy, habitat and ecology of all the species of the dragon tree group. These are found in thermo-sclerophyllous plant communities of tropical-subtropical regions which are rather xerophilous and have a rainfall range of $200-500 \mathrm{~mm}$. Our study indicates two independent colonization events for Dracaena in Macaronesia. In addition, we suggest that the dragon tree group provides an example of two major biogeographical disjunctions between East and West Africa. We postulate that this group has a Tethyan origin, a hypothesis supported by fossil and palaeoclimatic data, and thus parallels the distribution and dispersal pattern of other taxonomic groups.

(C) 1998 The Linnean Society of London

ADDITIONAL KEY WORDS:- Canary Islands - corology - ecology - Macaronesia.

CONTENTS

Introduction . . . . . . . . . . . . . . . . . . . . . . . . 292

Material and taxonomic references . . . . . . . . . . . . . . . . . . 294

Description . . . . . . . . . . . . . . . . . . . . . . 294

Dracaena tamaranae A. Marrero, R.S. Almeida \& M. González-Martín, sp. nov.

* Correspondence to A. Marrero. 


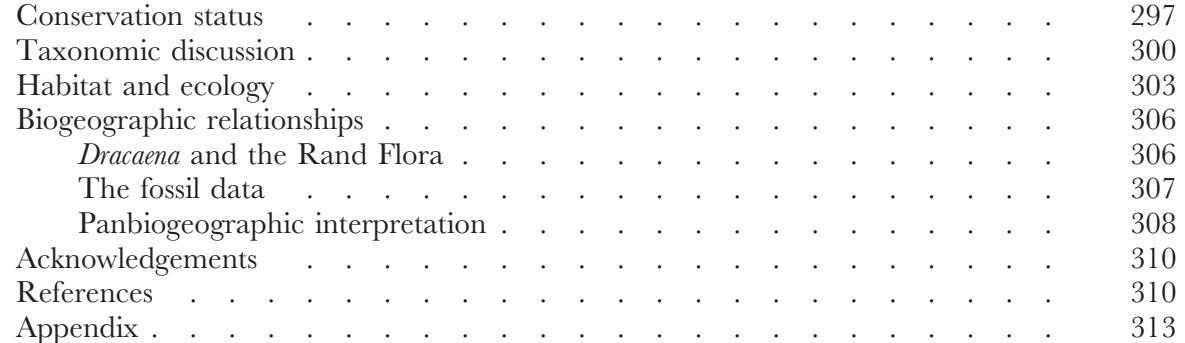

\section{INTRODUCTION}

The genus Dracaena comprises approximately 60 species (Mabberley, 1990) — 50 species sensu Friis (1992) — which are mainly found in tropical and subtropical Africa. At least 23 species occur in the Guinea-Congo region in western Africa (Bos, 1984). The genus also reaches Macaronesia, Arabia, Socotra, Madagascar, southeastern Asia, northern Australia, and one species (D. americana Donn. Sm.) is found in the neotropics.

The dragon tree group is formed of five arborescent species (i.e. D. cinnabari Balf. f., D. draco (L.) L., D. ombet Kotschy \& Peyr., D. serrulata Baker and D. schizantha Baker), and provides one of the best known examples of disjunct distribution between Macaronesia, Morocco and East Africa.

Until the discovery of the new species described here, Dracaena draco was the only species found in Macaronesia. It occurs in the Madeira archipelago, where it has been reported for the islands of Madeira and Porto Santo, although it is currently regarded as extinct in the latter. This species also thrives in the Canary Islands, where it is currently found on all the islands. However, wild populations of this species are only known in Tenerife and Gran Canaria; it is likely, therefore, that the present populations of $D$. draco in the rest of the archipelago are of cultivated origin. Dracaena draco also reaches the Cape Verde Islands where it is found on the islands of São Nicolau, Santo Antão and Fogo, and it is considered extinct on the islands of São Vicente and São Tiago (Byström, 1960). Dracaena draco has been recently discovered in southern Morocco, in the Anti-Atlas region, where it is regarded as a distinct taxon: D. draco subsp. ajgal Benabid et Cuzin (Benabid \& Cuzin, 1997).

Dracaena draco has been considered as closely related to the three species found in Socotra, D. cinnabari and East Africa, D. ombet (D. orabet sensu Engler, 1908), and D. schizantha (Balfour, 1883; Christ, 1885; Baker, 1898; Sunding, 1970). It is noteworthy that there is another species in Arabia (D. serrulata) which is usually ignored in accounts of the genus for the Red Sea region. These four East African and Arabian species have an allopatric distribution. Dracaena cinnabari is endemic to Socotra island where it thrives in the northeastern mountain range of Haggier (Balfour, 1883), mainly in the highlands of Mumi (Beyhl, 1995). Dracaena serrulata has a scattered distribution along the southwestern edge of the Arabian Peninsula, mainly in the hills of southern Medina and the El Asir mountains in Saudi Arabia; in the foothills of the highlands of Yemen and on northern slopes of Dhofar at Oman (Collenette, 1985; Miller \& Cope, 1996). Dracaena ombet grows along the African hills which face the Red Sea; it is found in Jebel Elba in southeastern Egypt, Mount Erkowit in Sudan, escarpments of the Eritrean mountains and in the mountains of Djibouti 


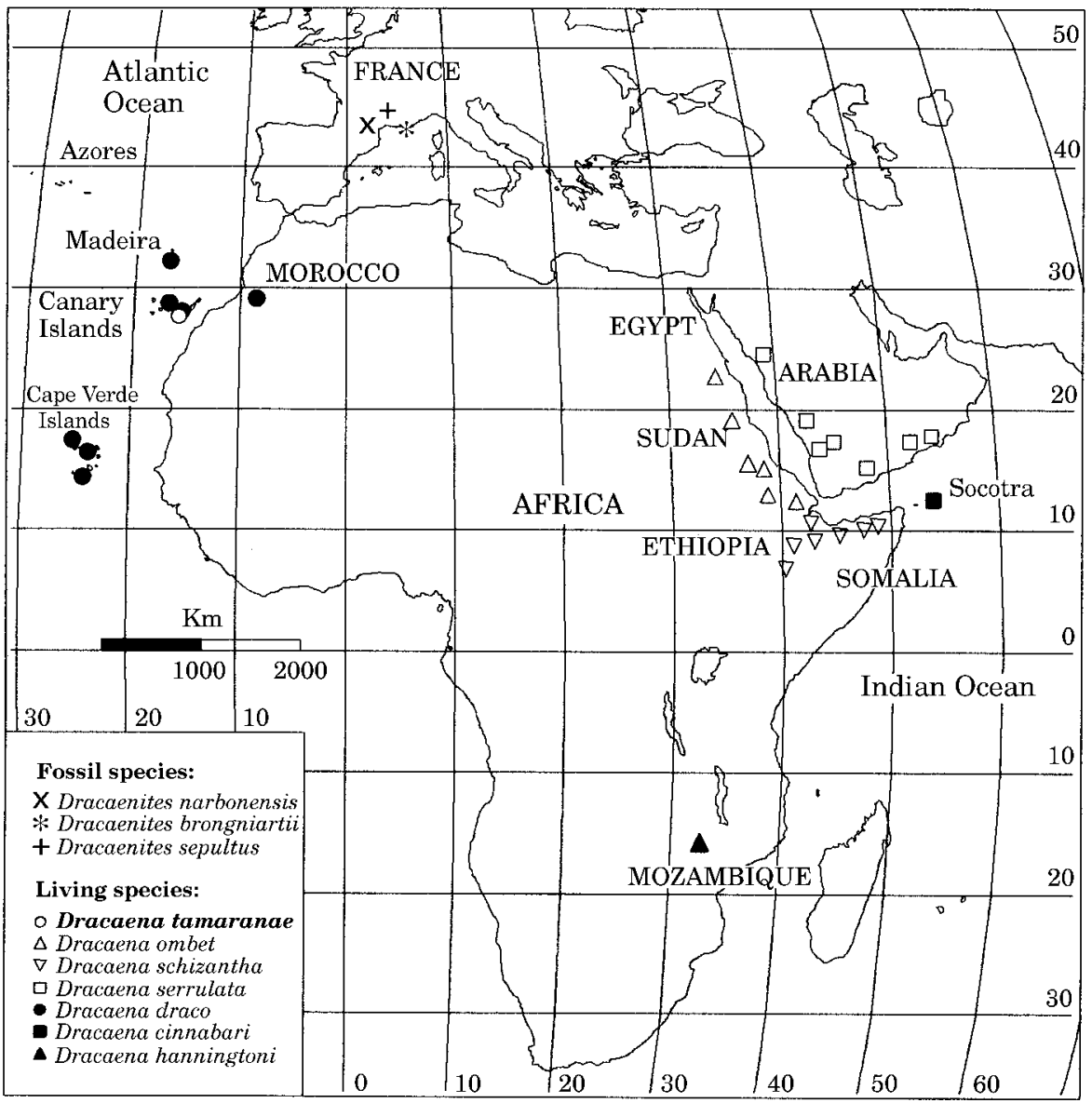

Figure 1. Distribution of the seven living species and three fossil species of the dragon tree group.

(Baker, 1897, 1898; Täckholm \& Drar, 1973; Friis, 1992). Lastly, D. schizantha is found in north-facing escarpments of Harar in Ethiopia, in the mountains of Djibouti and in the northern mountains of Somalia to the Ahl Mountains where it almost reaches the Horn of Africa (Baker, 1877; Friis, 1992; Thulin, 1995). A further species, D. hanningtoni Baker, restricted to Mozambique, also appears to be related to the five species which comprise the dragon tree group (Baker, 1898) (Fig. 1).

Wild dragon trees are extremely rare in Gran Canaria, and it was only in the early 1970s that they were reported for the first time, in the western mountains of Tauro and in the Barranco de Arguineguín (Kunkel, 1972, 1973). Most recently the distribution of this species has been mapped by Rodrigo \& Montelongo (1986). All these references identified the individuals as $D$. draco.

In the last 5 years one of us (R.S. Almeida) has undertaken extensive field studies relating to the distribution, phytogeography and conservation status of the wild dragon trees on Gran Canaria. As a result of these studies we were able to collect ripe fruits in 1994. Seedlings cultivated from these studies led us to the belief that the Gran Canaria individuals could not, in general, belong to D. draco. 
There are several morphological differences between the seedlings of these two species. The seedling leaves of $D$. draco are flat whereas those of the new taxon are conduplicate. In addition, the young root of the Gran Canaria endemic is napiform. These obvious differences in juvenile characters did also extend to other traits of adults such as the shape and habit of the inflorescence or the articulation of the pedicels.

\section{MATERIAL AND TAXONOMIC REFERENCES}

To conduct this study we have used morphological studies of living material and also of herbarium specimens (Appendix). It is also based on a critical review of several morphological descriptions of the different species of the dragon tree group: Linnaeus, 1767; Webb \& Berthelot, 1836-50; Hooker \& Smith, 1851; Schweinfurth, 1868; Baker, 1877, 1894, 1897, 1898; Bentham \& Hooker, 1880; Balfour, 1883, 1888; Engler, 1908; Brown, 1914; Andrews, 1956; Maire, 1958; Thonner, 1962; Täckholm \& Drar, 1973; Beyhl, 1995; Thulin, 1995; Turland, 1995; Benabid \& Cuzin, 1997.

\section{DESCRIPTION}

Dracaena tamaranae A. Marrero, R.S. Almeida \& M. González-Martín, sp. nov.

PLANTA arborescens robusta, 6-10 m alta, ramificatione primaria trichotoma, rare tetrachotoma et ramificationibus posterioribus dichotomis vel simplicibus. CORTEX flavo-griseus, vix signis foliaribus notatus, leviter nitidus. PLANTULAE foliis equitantibus bilateralibus compressis, radicibus valde succulentis, primariis cylindrico-globosis, secundariis napiformibus. FOLIA subulata, canaliculata, leviter falciformia, 40-80 $(110) \times 3-4.5 \mathrm{~cm}$, glauca, subtus leviter striata, margine omnino hyalina, ad basim incrassata cum pseudovagina fusco-rubinea, subamplexicauli, atque arcu manifesto et angusto, 10 (8-11) cm longo. INFLORESCENTIA paniculata complexa, glabra, tripinnata, gracilis, $80-100 \mathrm{~cm}$, per totam longitudinem ramificata. PEDUNGULUs brevissimus. BRACTEAE basales foliis similes, ad apicem cito decrescentes in formam diminutam, primum ensiforme demum subulatae et lineares, acuminatae. FLOREs $2-5$ in fasciculis dispositi. PEDIGelli 2.25-3.25 mm longi, ad apicem articulati. BRAGTEOlAE minutae, triangulares vel ovato-triangulares. PERIANTHIUM 9-15 mm, laete albo-viride; tepala oblongo-linearia, interna paulum angustiora quam exteriora, basi connati tubo brevissimo. STAMINA quam tepala breviora, ad stigma sub anthesi adiacentia; filamenta 6.5-9 mm, connata ad $2 \mathrm{~mm}$, leviter medio incrassata, non complanata; antherae $2 \mathrm{~mm}$, flavo-virides. Ovarium 3-loculare, $3.6 \times 2.4 \mathrm{~mm}$, ovulo in quoque loculo solitario. ovUlum stipitatum. sTYLus filiformis quam ovarium longior, $5.8 \mathrm{~mm}$, stigmate capitato trilobulato. FRUGTus glauco-virides, demum aurantiaci, globosi, 10-11.5 mm, vulgo monospermi. semina globosa vel late ovoidea, leviter compressa, 6-7 mm. 


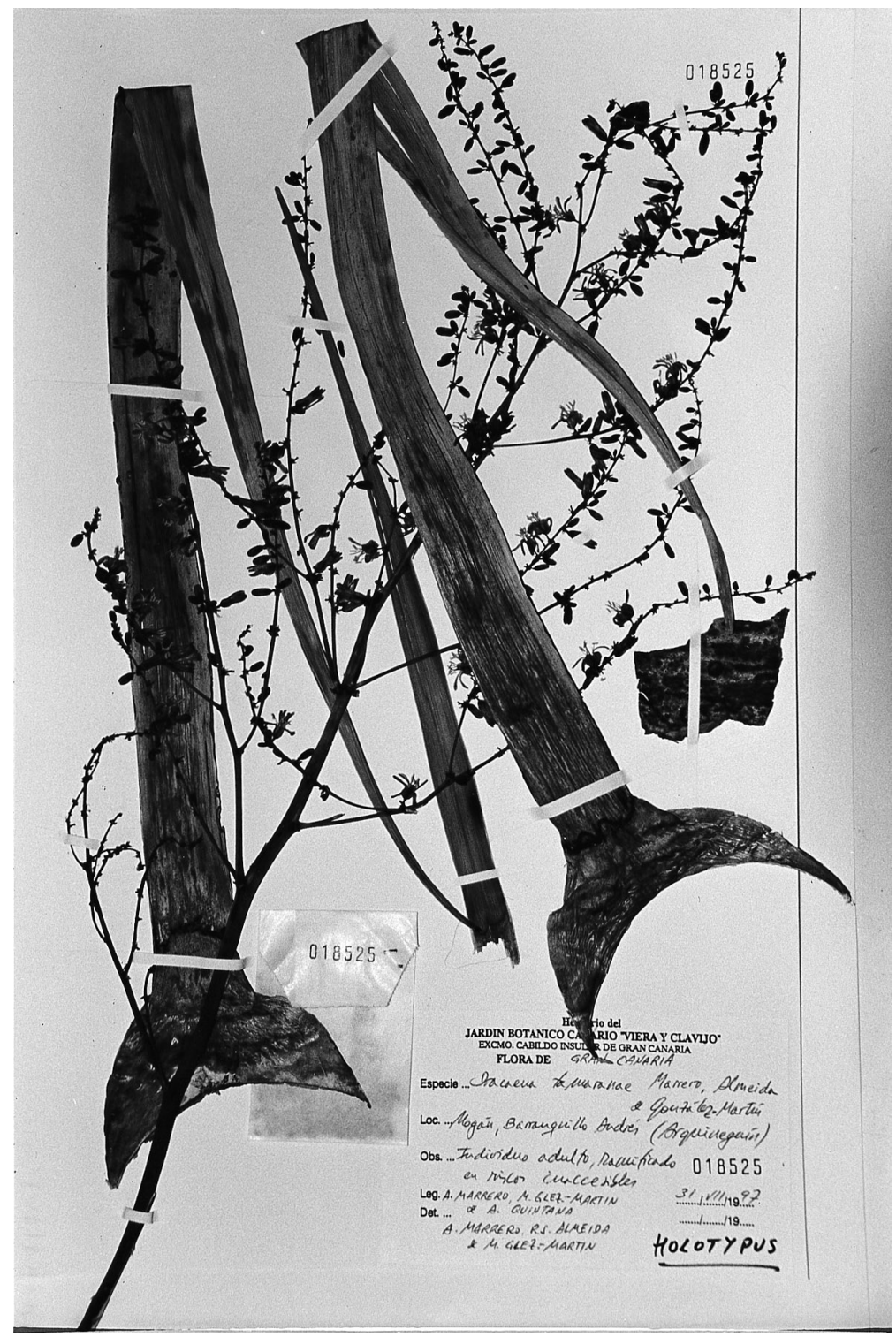

Figure 2. Holotype of Dracaena tamaranae A. Marrero, R.S. Almeida \& M. González-Martín, sp. nov.

Type. Dracaena tamaranae A. Marrero, R.S. Almeida \& M. González-Martín. Habitat in Canaria Magna (Gran Canaria dicta) in loco dicto "barranquillo Andrés", 825 m supra mare, loc. class. leg.: A. Marrero, M. González-Martín \& A. Quintana, die 31.vii.1997 (LPA:18525, holotypus in MA, Fig. 2). Isotypi: ibidem (duplicata in LPA, TFC, K), idem, R.S. Almeida, A. Marrero \& A. Quintana, 20.vii. 1997 (LPA: 18524 cum duplicata in MA, ORT, BM). (Icon: Fig. 3).

Additional material examined. Dracaena tamaranae A. Marrero, R.S. Almeida \& M. González-Martín, Gran Canaria, San Bartolomé de Tirajana, los Vicentillos, leg. 


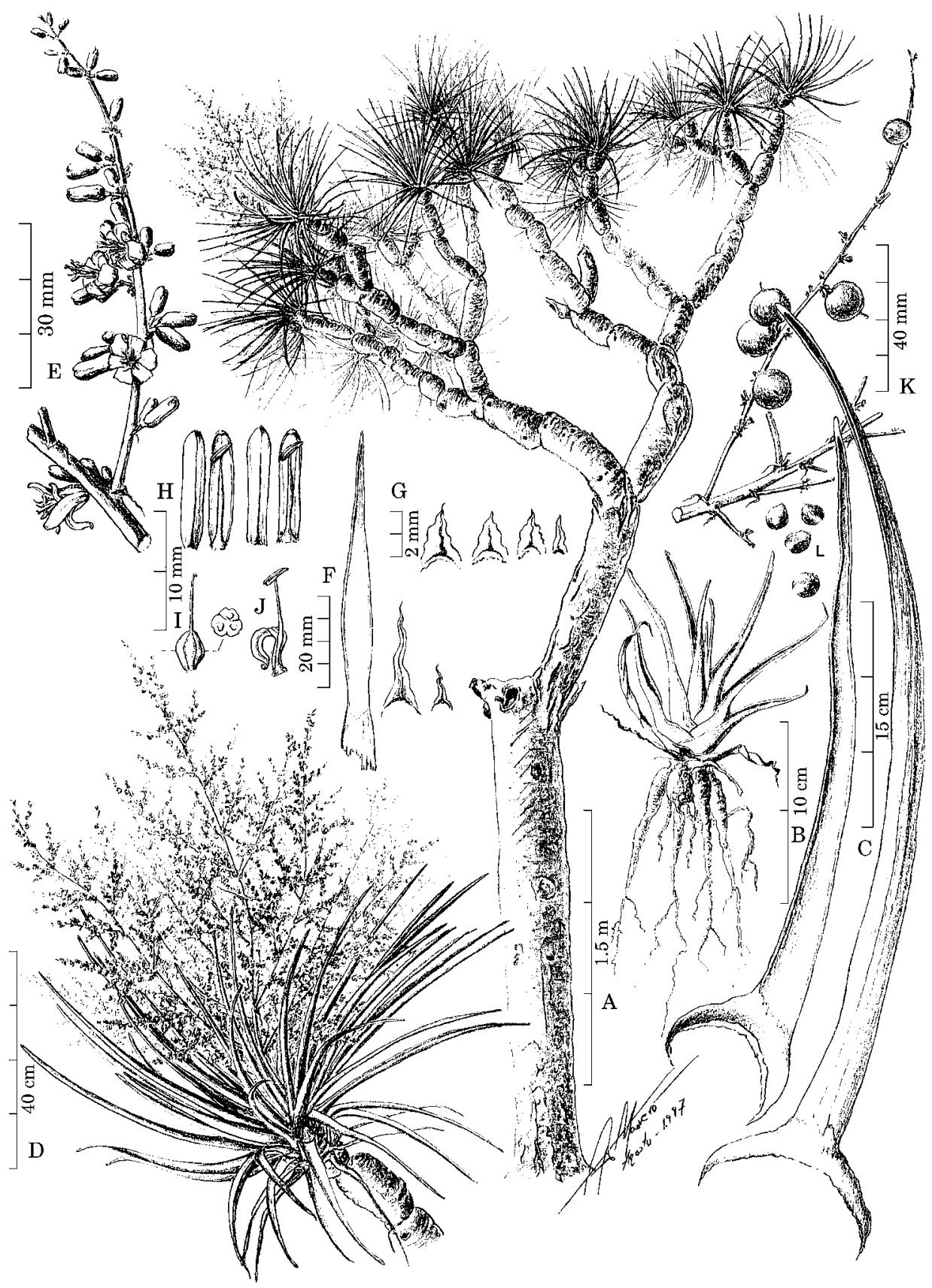

Figure 3. Icon: Dracaena tamaranae sp. nov. A, habit. B, seedling. G, leaves. D, terminal branch with inflorescence. E, flowers. F, bracts. G, bracteoles. H, tepals. I, pistil. J, stamens. K, fruits. L, seeds. 
R.S. Almeida \& A. Marrero, 17.vii.1997 (LPA: 18521); Ibidem, Mogán, barranco de Arguineguín, Los Peñones, leg. R.S. Almeida \& A. Marrero, 3.vii. 1997 (LPA: 18517); Ibidem, los Gavilanes, R.S. Almeida, A. Marrero \& M. González-Martín, 11.vii.1997 (LPA: 18518, 18519); Ibidem, El Palmarete, R.S. Almeida, A. Marrero \& M. González-Martín, 11.vii.1997 (LPA: 18520); Ibidem, Barranquillo Andrés, leg. R.S. Almeida, A. Marrero \& A. Quintana, 20.vii.1997 (LPA: 18522); Ibidem, ex horto, 193-194/96, A. Marrero, 26.vi.1997 (LPA: 18526, 18527) (seedling); Ibidem, barranco de Mogán, Los Laerones, leg. R.S. Almeida, A. Marrero \& M. González-Martín, 19.viii.1997 (LPA: 18523).

HABIT arborescent, robust, 6-10 m high, primary branching trichotomous, rarely tetrachotomous and subsequent branches dichotomous or simple. BARK yellow-grey, barely marked by foliar scars, slightly glossy. sEEDLINGs: leaves equitants, bilateral and compressed, roots highly succulent with a cylindrical globose primary root and napiform secondary roots (Fig. 4A). LEAVES $40-80$ (110) cm long, 3-4.5 cm wide, subulate and canaliculate, rather falcate, glaucous, rather striate below, hyalinewhite entire margin, swollen at the base with a basal brown-reddish pseudo-sheath which is subamplexicaul and forms a patent and narrow arc $10(8-11) \mathrm{cm}$ long. INFLORESGENGE $80-100 \mathrm{~cm}$ long, panicle complex, glabrous, tripinnate, slender, branches dispersed along the main axis (Fig. 4B). PEDUNCLE very short. BRAGTs basals are similar to the mature leaves, secondary bracts decrease rapidly in size, ensiform to subulate and linear, acuminate. FLOWERS $2-5$ clustered. PEDICEL $2.25-3.25 \mathrm{~mm}$ long, articulate towards the apex. BRACTEOLES minute, triangular or ovate-triangular. PERIANTH 9.5-11 mm, bright greenish-white, tepals oblong-linear, inner tepals narrower than outer ones, joined at the base, tube very short. sTAMENs shorter than tepals and adjacent to the stigma during anthesis; filaments $6.5-9 \mathrm{~mm}$, joined $2 \mathrm{~mm}$ from the base, slightly swollen in the middle, unflattened; anthers $2 \mathrm{~mm}$, yellowgreenish. OVARY trilocular $3.6 \times 2.4 \mathrm{~mm}$, with a single, stipitate ovule per locule. STYLE $5.8 \mathrm{~mm}$, filiform, longer than the ovary; stigma capitate, trilobulate. FRUITS $10-11.5 \mathrm{~mm}$ globose, greenish, glaucous but orange when ripe, usually monospermous. SEEDS $6-7 \mathrm{~mm}$ globose to broadly ovoid and slightly compressed (Tables $1-4)$.

Dracaena tamaranae is a species restricted to the island of Gran Canaria, Canary Islands. This species is found between 400 and $900 \mathrm{~m}$ altitude, and along an arc in the southwestern region, from Fataga valley in the southern slopes to La Aldea valley in the west.

\section{CONSERVATION STATUS}

This species is extremely rare and is known from few localities. We propose that it merits CR status (Critically Endangered) in the IUCN (IUCN, Red List Categories, 1994). Although some populations are located within the network of Gran Canaria nature reserves (Act 12/94 Espacios Naturales de Canarias) there are still many unprotected individuals. There is a strong need to establish a rescue programme to preserve the genetic integrity of this species. 

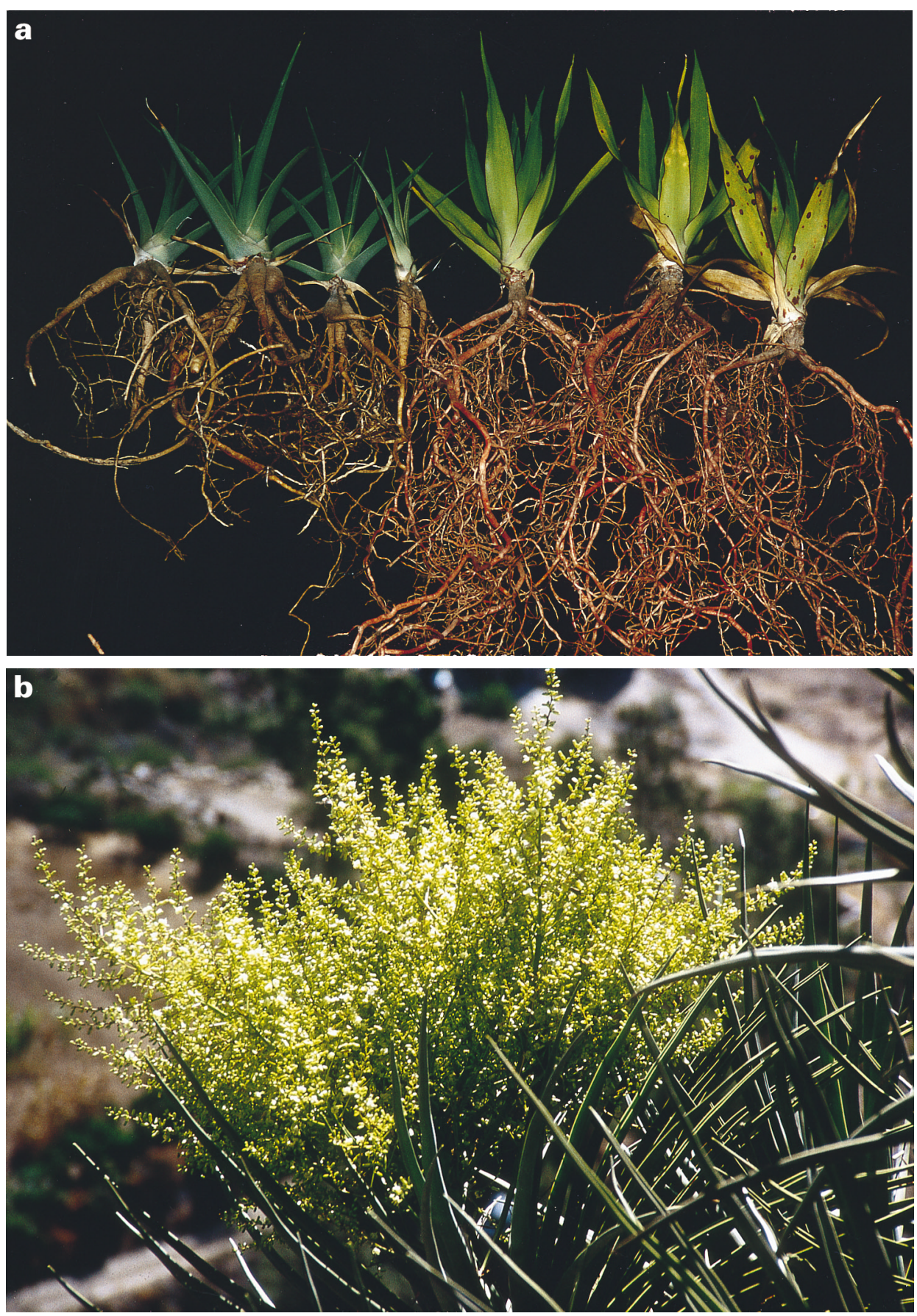

Figure 4. A, seedling of Dracaena tamaranae sp. nov. (left) and D. draco (right). B, inflorescence of D. tamaranae sp. nov. 
NEW SPECIES OF DRACAENA FROM GRAN CANARIA

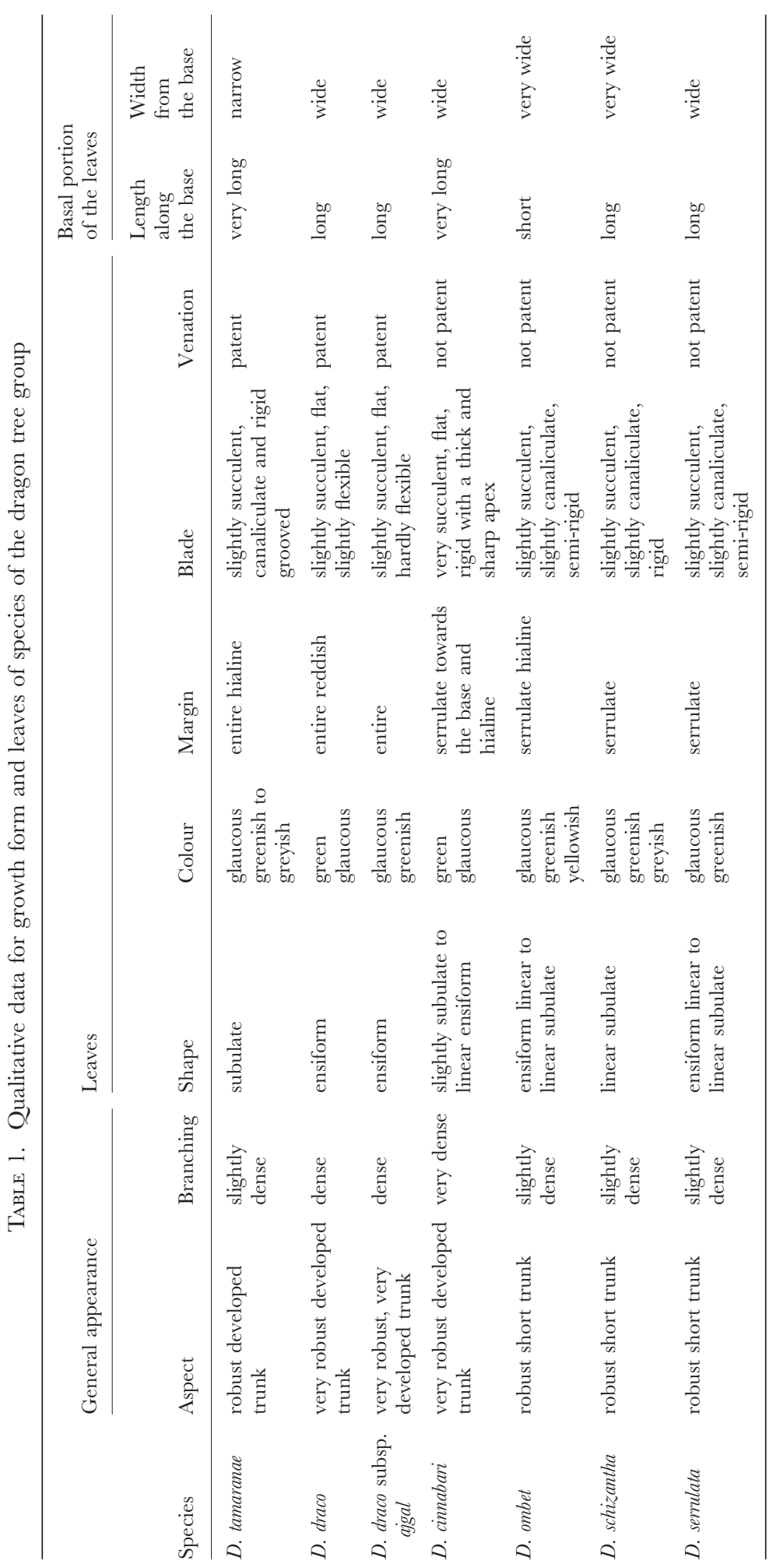


TABLE 2. Qualitative data for flower traits of species of the dragon tree group

\begin{tabular}{|c|c|c|c|c|c|c|}
\hline \multirow[b]{2}{*}{ Species } & \multicolumn{2}{|c|}{ Inflorescence } & \multirow[b]{2}{*}{ Bracts } & \multirow[b]{2}{*}{ Bracteoles } & \multicolumn{2}{|c|}{ Pedicels } \\
\hline & Ramification & Hairiness & & & Articulation & $\mathrm{n}^{\circ} /$ cluster \\
\hline D. tamaranae & $\begin{array}{l}\text { tripinnate } \\
\text { along the axes }\end{array}$ & glabrous & $\begin{array}{l}\text { subulate-linear, } \\
\text { acuminate }\end{array}$ & $\begin{array}{l}\text { triangular-ovat } \\
\text { minute }\end{array}$ & $\begin{array}{l}\text { te, apical } \\
\text { extreme }\end{array}$ & $3-5$ \\
\hline D. draco & $\begin{array}{l}\text { bipinnate } \\
\text { below the } \\
\text { middle }\end{array}$ & glabrous & $\begin{array}{l}\text { linear-subulate, } \\
\text { acuminate }\end{array}$ & $\begin{array}{l}\text { subulate ovate, } \\
\text { acuminate }\end{array}$ & middle & $4-7$ \\
\hline $\begin{array}{l}\text { D. draco subsp. } \\
\text { ajgal }\end{array}$ & $\begin{array}{l}\text { bipinnate } \\
\text { below the } \\
\text { middle }\end{array}$ & glabrous & $\begin{array}{l}\text { linear-subulate, } \\
\text { acuminate }\end{array}$ & $\begin{array}{l}\text { subulate ovate, } \\
\text { acuminate }\end{array}$ & middle & $4-7$ \\
\hline D. cinnabari & $\begin{array}{l}\text { bipinnate } \\
\text { middle }\end{array}$ & glabrous & $\begin{array}{l}\text { subulate to } \\
\text { subulate- } \\
\text { acuminate }\end{array}$ & $\begin{array}{l}\text { triangular-ovat } \\
\text { acuminate }\end{array}$ & $\begin{array}{l}\text { middle } \\
\text { extreme }\end{array}$ & $3-7$ \\
\hline D. ombet & $\begin{array}{l}\text { tripinnate } \\
\text { along the axes }\end{array}$ & glabrescens & $\begin{array}{l}\text { triangular, } \\
\text { acuminate }\end{array}$ & ovate minute & middle & - \\
\hline D. schizantha & $\begin{array}{l}\text { tripinnate } \\
\text { along the axes }\end{array}$ & $\begin{array}{l}\text { felted } \\
\text { tomentose }\end{array}$ & $\begin{array}{l}\text { subulate } \\
\text { triangular, } \\
\text { acuminate, }\end{array}$ & $\begin{array}{l}\text { triangular, } \\
\text { acuminate } \\
\text { minute }\end{array}$ & $\begin{array}{l}\text { middle to } \\
\text { middle } \\
\text { extreme }\end{array}$ & $1-4$ \\
\hline \multirow[t]{2}{*}{ D. serrulata } & $\begin{array}{l}\text { tripinnate } \\
\text { along the axes }\end{array}$ & $\begin{array}{l}\text { tomentose or } \\
\text { dense } \\
\text { tomentose }\end{array}$ & $\begin{array}{l}\text { subulate, } \\
\text { triangular, } \\
\text { acuminate }\end{array}$ & $\begin{array}{l}\text { triangular, } \\
\text { subulate } \\
\text { acuminate }\end{array}$ & $\begin{array}{l}\text { middle to } \\
\text { middle } \\
\text { extreme }\end{array}$ & $1-5$ \\
\hline & \multicolumn{3}{|c|}{ Perianth } & \multicolumn{2}{|c|}{ Stamens } & Fruits \\
\hline Species & Segment & Tube & Colour & Anthers & Filament & Colour \\
\hline D. tamaranae & oblong linear & very short & whitish green & $\begin{array}{l}\frac{1}{3} \frac{1}{4} \\
\text { filament }\end{array}$ & $\begin{array}{l}\text { slightly } \\
\text { thickened, not } \\
\text { flattened }\end{array}$ & orange \\
\hline D. draco & $\begin{array}{l}\text { subspatulate } \\
\text { linear }\end{array}$ & $\begin{array}{l}\text { short } \\
\text { campanulate }\end{array}$ & whitish pink & $\begin{array}{l}\frac{1}{2} \frac{1}{3} \\
\text { filament }\end{array}$ & $\begin{array}{l}\text { thickened } \\
\text { flattened }\end{array}$ & $\begin{array}{l}\text { orange } \\
\text { reddish }\end{array}$ \\
\hline $\begin{array}{l}\text { D. draco subsp. } \\
\text { ajgal }\end{array}$ & $\begin{array}{l}\text { subspatulate } \\
\text { linear }\end{array}$ & $\begin{array}{l}\text { short } \\
\text { campanulate }\end{array}$ & whitish yellow & $\begin{array}{l}\frac{1}{2} \frac{1}{3} \\
\text { filament }\end{array}$ & $\begin{array}{l}\text { thickened } \\
\text { flattened }\end{array}$ & $\begin{array}{l}\text { red } \\
\text { orange }\end{array}$ \\
\hline D. cinnabari & oblong & $\begin{array}{l}\text { basal and } \\
\text { barely } \\
\text { developed }\end{array}$ & $\begin{array}{l}\text { pale greenish } \\
\text { yellow }\end{array}$ & $\begin{array}{l}\text { twice } \\
\text { filament }\end{array}$ & subulate & $\begin{array}{l}\text { red } \\
\text { scarlet }\end{array}$ \\
\hline D. ombet & linear & $\begin{array}{l}\text { very short, } \\
\text { barely } \\
\text { developed }\end{array}$ & whitish pink & $\begin{array}{l}\text { subequal } \\
\text { filament }\end{array}$ & - & - \\
\hline D. schizantha & lanceolate & $\begin{array}{l}\text { very short, } \\
\text { barely } \\
\text { developed }\end{array}$ & white & $\begin{array}{l}\frac{1}{2}-\frac{1}{3} \\
\text { filament }\end{array}$ & $\begin{array}{l}\text { subulate } \\
\text { thickened }\end{array}$ & - \\
\hline D. serrulata & - & - & - & - & - & orange \\
\hline
\end{tabular}

\section{TAXONOMIC DISCUSSION}

Dracaena tamaranae sp. nov. seems to be closely related to the three species found in the Horn of Africa and Arabia (i.e. D. ombet, D. schizantha and D. serrulata). All these species have glaucous leaves, minute bracteoles and are not densely branched. 
TABle 3. Quantitative data for growth form, leaves and inflorescences of species of the dragon tree group. 1/w = length/width

\begin{tabular}{|c|c|c|c|c|c|}
\hline \multirow[b]{2}{*}{ Species } & \multirow[b]{2}{*}{$\begin{array}{l}\text { Height } \\
\text { (m) }\end{array}$} & \multicolumn{4}{|c|}{ Leaves } \\
\hline & & $\begin{array}{l}\text { Length } \\
(\mathrm{cm})\end{array}$ & $\begin{array}{l}\text { Width } \\
(\mathrm{cm})\end{array}$ & $1 / w$ & $\begin{array}{l}\text { Base } \\
(\mathrm{cm})\end{array}$ \\
\hline D. tamaranae & $6-10$ & $40-80(110)$ & $3-4.5(5)$ & $10-18$ & $9.8-19.4 \times 3.7-5.5$ \\
\hline D. draco & $8-12$ & $40-90(110)$ & $2-3.5(4)$ & $20-25$ & $6-10.4 \times 3-4.2$ \\
\hline D. draco subsp. ajgal & $10-20$ & 60 & 3 & 20 & - \\
\hline D. cinnabari & $6-10$ & $30-60$ & $2.5-4.5$ & $12-13.3$ & $6.5-13.5 \times 2.2-5$ \\
\hline$D$ ombet & $2-8$ & $35-65$ & $2.2-3$ & $16-21.7$ & $4.5-8 \times 3.2-5.6$ \\
\hline D. schizantha & $2-9$ & $35-70$ & $0.7-2.5$ & $28-50$ & $4.5 \times 2.4-3.7$ \\
\hline \multirow[t]{2}{*}{ D. serrulata } & $2-8$ & $30-60$ & 2-3.5 & $15-17$ & $8-10 \times 2.5-4.5$ \\
\hline & \multicolumn{5}{|c|}{ Inflorescence } \\
\hline Species & $\begin{array}{l}\text { Length } \\
\text { (cm) }\end{array}$ & $\begin{array}{l}\text { Flower pedicels } \\
(\mathrm{mm})\end{array}$ & & $\begin{array}{l}\text { Fruit pedicels } \\
\qquad(\mathrm{mm})\end{array}$ & $\begin{array}{l}\text { Bracteoles } \\
\quad(\mathrm{mm})\end{array}$ \\
\hline D. tamaranae & $80-100$ & $2.25-3.25$ & & - & 1.90 \\
\hline D. draco & $60-120$ & $4.00-6.00(10)$ & & $8.30-10.50$ & $0.80-2.80$ \\
\hline D. draco subsp. ajgal & - & $1.00-4.00$ & & - & - \\
\hline D. cinnabari & $30-75$ & $3.00-7.00$ & & $6.00-8.00$ & $1.00-4.00$ \\
\hline D ombet & $20-40$ & $3.10-4.50$ & & $\begin{array}{c}\text { semipedicel } \\
2.50-4.50\end{array}$ & $0.50-1.50$ \\
\hline D. schizantha & 45 & $1.50-3.00$ & & $3.50-5.00$ & $0.50-1.50$ \\
\hline D. serrulata & - & - & & $2.50-5.00$ & $0.50-1.50$ \\
\hline
\end{tabular}

TABLE 4. Quantitative data for flower and fruit traits of species of the dragon tree group

\begin{tabular}{|c|c|c|c|c|c|c|c|}
\hline \multirow[b]{2}{*}{ Species } & \multicolumn{2}{|c|}{ Flowers } & \multicolumn{2}{|c|}{ Stamens } & \multirow{2}{*}{$\begin{array}{c}\text { Ovary } \\
\text { length } \\
(\mathrm{mm})\end{array}$} & \multirow{2}{*}{$\begin{array}{c}\text { Fruit } \\
\text { diameter } \\
(\mathrm{mm})\end{array}$} & \multirow{2}{*}{$\begin{array}{l}\text { Seed } \\
\text { size } \\
(\mathrm{mm})\end{array}$} \\
\hline & $\begin{array}{l}\text { Perianth } \\
\quad(\mathrm{mm})\end{array}$ & $\begin{array}{l}\text { Tube } \\
(\mathrm{mm})\end{array}$ & $\begin{array}{l}\text { Filament } \\
(\mathrm{mm})\end{array}$ & $\begin{array}{l}\text { Anther } \\
(\mathrm{mm})\end{array}$ & & & \\
\hline D. tamaranae & $9.50-11.00$ & $0.75-1.00$ & $6.08-8.75$ & $1.75-2.00$ & $3.50-3.75$ & $10.00-11.50$ & $6.00-7.00$ \\
\hline D. draco & $7.00-9.50$ & $1.30-3.50$ & $5.80-8.00$ & $1.00-1.50$ & $3.60-4.50$ & $14.30-14.60$ & $7.50-10.00$ \\
\hline D. draco subsp. ajgal & $7.00-8.00$ & $1.00-2.00$ & - & - & - & - & $7.50-10.00 ?$ \\
\hline D. cinnabari & $5.00-9.50$ & - & - & $2.00-2.25$ & $3.50-4.00$ & $8.00-13.00$ & $3.50-5.00$ \\
\hline D. ombet & $6.30-6.40$ & - & - & - & - & - & - \\
\hline D. schizantha & $3.50-6.50$ & - & $3.20-4.75$ & $1.00-1.50$ & $2.75-3.00$ & $5.00-7.00$ & - \\
\hline D. serrulata & 5.00 & - & - & - & - & $5.00-8.00$ & $3.50-5.50$ \\
\hline
\end{tabular}

In addition, the tripinnate, slender and erect inflorescences are branched along all the axes.

These continental species have flowers and inflorescences which are smaller than those of $D$. tamaranae. Furthermore, they also have rather succulent and linearensiform leaves with acutely serrulated margin and no patent nerves, the trunks are usually shorter and the pedicels are articulated in the middle section. Moreover, $D$. schizantha tends to have linear leaves which are extremely narrow and greyish in colour, it has tomentose panicles which are dense and short. The basal pseudosheaths of the leaves of $D$. ombet are only slightly developed, and this species has 
glabrescent inflorescences. Plants of $D$. serrulata are distinguished from the Gran Canaria species by their tomentose inflorescence.

There are several morphological characters which differentiate $D$. tamaranae from $D$. draco and $D$. cinnabari. These two latter species have ensiform leaves which are flat and not as glaucous, their inflorescences are bipinnate and robust. In addition, the branching of the inflorescences is basal. Other unique features of these species are pedicels articulated in the middle, smaller perianth, flattened filaments and a robust and dense growth-form. Furthermore, D. cinnabari has extremely rigid leaves with finely serrate margin towards the base, and nerves which are not patent. In contrast $D$. draco usually has reddish leaf-margins, inflorescence branches which tend to be reflexed or patent after fruiting, linear, acuminate inflorescence bracts and a whitish-pink perianth with a longer tube. Dracaena hanningtoni seems to be closely related to D. ombet (Baker, 1898), and it is rather different from the other species of the dragon tree group in that it has a much longer perianth, with the segments twice as long as the tube, the stamens are as long as the segments and the style is exserted. However, the general shape of the inflorescence indicates that this species seems to be closely related to the $D$. draco-D. cinnabari group.

We consider that $D$. tamaranae has strong morphological relationships with the East African and Arabian species. The main morphological features which support this hypothesis are the type of inflorescence and the general habit. However, we postulate that $D$. draco is closely related to the Socotra species, $D$. cinnabari. This assumption would mean that there are two biogeographical disjunctions between Macaronesia and the Red Sea region. A phylogenetic confirmation of this hypothesis would provide one of the few cases for independent colonizations of oceanic islands by congeneric species. Previous studies based on molecular data have proven this to be the case for Lavatera (Malvaceae) in the Canary Islands (Ray, 1995; FuertesAguilar et al., 1996) and for Gossypium (Malvaceae) in Galapagos (Wendel \& Percival, 1990; Wendel \& Percy, 1990). It is likely that other genera such as Convolvulus, Euphorbia, Limonium, Salvia, Senecio or Viola, with endemic species in Macaronesia, have also colonized these islands more than once.

Two species, $D$. draco and $D$. tamaranae, occur in western Africa. The former occurs both on the mainland and the Macaronesian Islands, whilst the latter is restricted to Gran Canaria. The occurrence of the insular species can only be explained through long-distance dispersal because these islands appear to be oceanic and therefore have never been joined to the continent (Araña \& Carracedo, 1978; Araña \& Ortiz, 1984; Carracedo, 1984). It is likely that these two species remained in a refuge in the Macaronesian Islands, and following a decrease of continental populations of dragon trees from western Africa. D. draco is now only found in a very restricted area of southern Morocco. It is noteworthy that these Morocco populations have been given subspecies rank as $D$. draco subsp. ajgal, an indication that the taxon is in early stages of speciation (Fig. 5A).

The geological events which led to the formation of the African Great Rift have had an impact in the current distribution of dragon trees in East Africa. In this region the Great Rift splits into two major fissures, one towards the Red Sea, the other towards the Aden Gulf. These geological events began in the early Miocene and resulted in the fragmentation of the original populations of dragon trees. These new sub-populations probably initiated new speciation events which yielded the three species which currently thrive in Arabia (D. serrulata), the African hills of the Red Sea $(D$. ombet $)$ and the Horn of Africa $(D$. schizantha). These three species are 


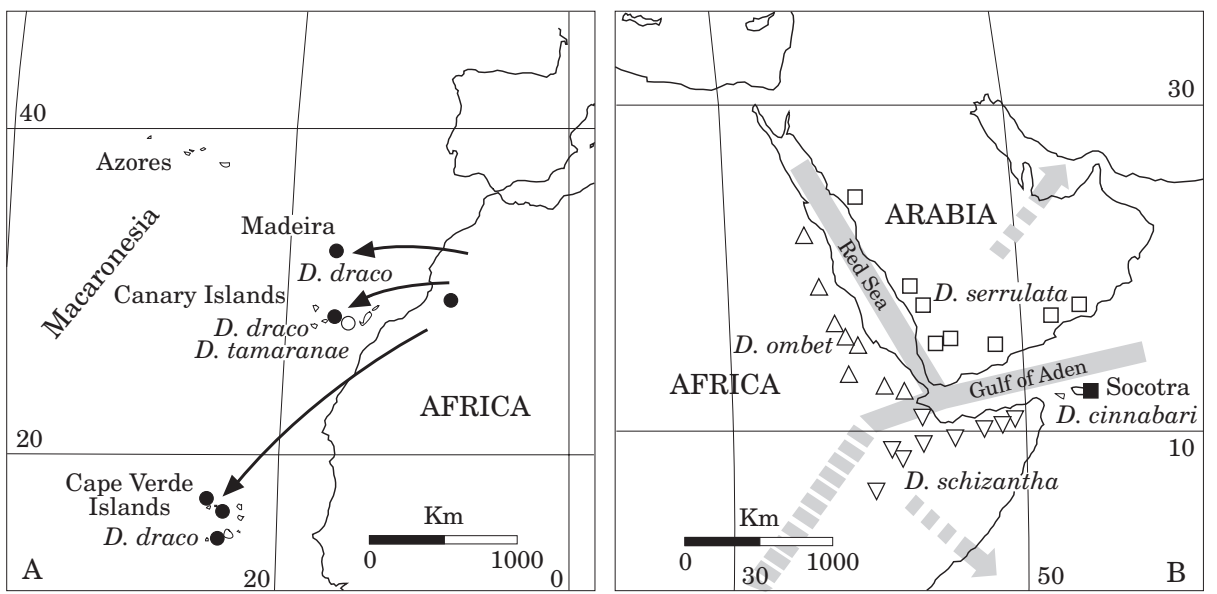

Figure 5. A, dispersal and colonization from the African mainland make the Macaronesian Islands a refuge for several species of Dracaena. B, African Grand Rift leads to the disruption and vicariance of Dracaena in the Red Sea region.

closely related, and they might form a species complex; indeed, some authors have suggested that they are conspecific with D. ombet s.l. (Deil, 1988; Friis, 1992; Thulin, 1995). However, Miller \& Cope (1996) considered D. serrulata to be a distinct species. Our preliminary studies indicate that $D$. schizantha also has some morphological differences. In contrast, $D$. cinnabari is a distinct species which has several unique morphological features. It is restricted to the continental island of Socotra. This island was part of the Horn of Africa before the Middle Pliocene (Fig. 5B).

Saporta (1862, 1865, 1873a,b) described three Neogene fossil species of dragon tree (Dracaenites brongniartii Saporta, D. sepultus Saporta and D. narbonensis Saporta) from southern France, which he suggested were closely related to $D$. draco. However, at that time the dragon trees of East Africa and Arabia were not known to the scientific community. Dracaenites brongniartii, like Dracaena draco and D. cinnabari, has ensiform leaves. Plants of $D$. ombet s.l. have linear-ensiform leaves, but they are never truly ensiform. The two other fossil species have strictly linear leaves and, therefore, they may be related to those species which have subulate-linear or linear-ensiform leaves (Table 5). All the species have foliar scars in the bark, and these are particularly evident in the $D$. ombet group and $D$. cinnabari. The foliar scars have a rough margin in D. cinnabari. In contrast, they are tenuous in the fossil species and in D. tamaranae. Dracaenites sepultus has an extremely warty bark, a feature which is unknown in any of the living species. However, we are aware that based on these morphological features, it is difficult to establish phylogenetic links between the fossil species and the present ones. There is no reason to assume that these fossils represent the direct ancestors of the living species. Sadly there are no fossils of fruits and flowers which would help to clarify this issue.

\section{HABITAT AND ECOLOGY}

Dracaena tamaranae sp. nov. is found in the thermophile zone where it grows on inaccessible slopes and cliffs which tend to be shady and humid. The open Funiperus 
TABle 5. A selection of the most important morphological features of several fossil species (Dracaenites) from the French Tertiary

\begin{tabular}{|c|c|c|c|c|c|c|c|}
\hline \multirow[b]{2}{*}{ Fossil taxon } & \multirow[b]{2}{*}{ Locality } & & \multirow[b]{2}{*}{ Stipe } & \multicolumn{3}{|c|}{ Leaf branches } & \multirow[b]{2}{*}{ Foliar scars } \\
\hline & & & & Diameter & \multicolumn{2}{|c|}{ Bark } & \\
\hline D. narbonensis & \multicolumn{2}{|l|}{ Armissan } & arboreal & $10 \mathrm{~cm}$ & \multicolumn{2}{|c|}{$\begin{array}{l}\text { slightly rough } \\
\text { without protuberance }\end{array}$} & ance ${ }^{\text {slightly patent }}$ \\
\hline D. sepultus & \multicolumn{2}{|c|}{ Aix, Provence } & bush & - & \multicolumn{2}{|c|}{$\begin{array}{l}\text { warty with } \\
\text { protuberance }\end{array}$} & very tenuous \\
\hline D. brongniartii & \multicolumn{2}{|c|}{ Aix, Provence } & giant & $10 \mathrm{~cm}$ & \multicolumn{2}{|c|}{-} & - \\
\hline \multirow[t]{2}{*}{ D. minor } & \multicolumn{2}{|c|}{ Aix, Provence } & frutescens & - & \multicolumn{2}{|l|}{-} & very patent \\
\hline & \multicolumn{7}{|c|}{ Leaves } \\
\hline Fossil taxon & Shape & \multicolumn{2}{|c|}{$\begin{array}{l}\text { Outward } \\
\text { appearance }\end{array}$} & Venation & Length & Width & Base \\
\hline D. narbonensis & linear & \multicolumn{2}{|c|}{$\begin{array}{l}\text { flat with margin } \\
\text { entire }\end{array}$} & delicately nerved & $150 \mathrm{~cm}$ & $4 \mathrm{~cm}$ & $\begin{array}{l}\text { gradually expanded } \\
10-12 \mathrm{~cm}\end{array}$ \\
\hline D. sepultus & linear & \multicolumn{2}{|c|}{ firm } & nerved & - & - & broad \\
\hline D. brongniartii & ensiform & \multicolumn{2}{|c|}{ rigid and firm } & nerved striated & - & $3 \mathrm{~cm}$ & $\begin{array}{l}\text { clearly broad } \\
10-12 \mathrm{~cm}\end{array}$ \\
\hline D. minor & $\begin{array}{l}\text { strictly } \\
\text { linear }\end{array}$ & \multicolumn{2}{|c|}{ shiny and firm } & $\begin{array}{l}\text { very tenuous } \\
\text { delicate } \\
\text { compressed } \\
\text { unequal }\end{array}$ & \multicolumn{2}{|c|}{$\begin{array}{l}\text { extremely - } \\
\text { long }\end{array}$} & $\begin{array}{l}\text { little and sharply } \\
\text { expanded }\end{array}$ \\
\hline
\end{tabular}

bushland (Oleo-Rhamnetalia crenulatae Santos 1983) and the Cistus scrubland (CistoMicromerietalia P. Pérez et al. 1991) form a mosaic in this area. Species which grow in this zone are: Juniperus turbinata Guss. subsp. canariensis (Guyot) Rivas Mart., Wildpret \& P. Pérez, Olea europaea L. subsp. cerasiformis (Webb \& Berthel.) G. Kunkel \& Sunding, Teline rosmarinifolia Webb \& Berthel., Globularia of. salicina Lam., etc. (Rodrigo \& Montelongo, 1986; Marrero, González-Artiles \& González-Martín, 1995). Species which are characteristic of northern and northeastern humid slopes of the archipelago also occur in this area. Among these are: Davallia canariensis (L.) J.E. Sm., Pericallis webbii (Sch. Bip.) Bolle, Sonchus acaulis Dum. Cours., Hypericum canariense L., Ranunculus cortusifolius Willd., etc. Dracaena tamaranae reaches the dry canary pine forest (Cytiso-Pinetea canariensis Rivas Goday \& Esteve ex Sunding 1972) at higher altitude. This species can also be found at lower altitude among elements of the Kleinio-Euphorbietalia canariensis (Rivas Goday \& Esteve 1965) Santos 1976. The average annual rainfall of the zones where $D$. tamaranae grows is $200-350 \mathrm{~mm}$.

Both in Macaronesia and Morocco, $D$. draco lives in areas which are not as xeric as those of D. tamaranae. For instance, on Madeira, it is mainly found as an element of thermo-sclerophyllous zones between sea-level and $200 \mathrm{~m}$, and on sea-facing cliffs where some species of the laurel forest also occur (Turland, 1995). On Tenerife, $D$. draco also grows in thermo-sclerophyllous zones (Mayteno-funiperion canariensis Santos \& Fernández Galván ex Santos 1983) between 100 and $600 \mathrm{~m}$. Other species found in this zone are: Funiperus turbinata subsp. canariensis, Maytenus canariensis (Loes.) G. Kunkel \& Sunding, Rhamnus crenulata Aiton, Olea europaea subsp. cerasiformis, Pistacia 
atlantica Desf., Globularia salicina, etc. (Santos, 1983; Rivas Martíez et al., 1993). In addition, Sideroxylon marmulano Banks ex Lowe and Apollonias barbujana (Cav.) Bornm., two thermophile species of the laurel forest, are also found in this zone. The annual average rainfall of this zone ranges between 200 and $400 \mathrm{~mm}$. On Gran Canaria this species grows in similar areas, but it is extremely rare. On Cape Verde Islands, Dracaena draco is found between 700 and $1000 \mathrm{~m}$ where it grows together with Euphorbia tuckeyana Steud. ex Webb, Echium spp., Ficus sur Forssk. (F. capensis Thunb.), F. sycomorus L. subsp. gnaphalocarpa (Miq.) C.C. Berg, Sideroxylon marmulano, Acacia albida Del., etc. (Byström, 1960). The Anti-Atlas populations of D. draco are located between 400 and $1300 \mathrm{~m}$ with Laurus azorica (Seub.) Franco, Davallia canariensis, Rhamnus alaternus L., Quercus rotundifolia Lam., Ceratonia siliqua L., Teline segonnei (Maire) Reynaud, Argania spinosa Skeels, Olea maroccana Greuter \& Burdet, etc. These species are part of the association Davallio canariensis-Dracaenetum ajgal Benabid \& Cuzin 1997 in the order Acacio-Arganietalia Barbéro et al. 1982 (Benabid \& Cuzin, 1997). Annual rainfall is around $400 \mathrm{~mm}$. However, Rivas-Goday \& Esteve-Chueca (1965) defined the thermo-sclerophyllous shrubs with Dracaena draco as the climax of the CrassiEuphorbietea, Diacanthio-Euphorbietea (Kleinio-Euphorbietea).

The ecology of these species is similar to that of all the East African and Arabian species. For example, $D$. ombet is usually found in mountain escarpments together with O. europaea subsp. africana (Mill.) P.S. Green (including O. chrysophylla Lam.), Euclea racemosa Murr., Euphorbia abyssinica J.F. Gmel., Acacia etbaica Schweinf., A. tortilis (Forssk.) Hayne, Ziziphus spina-christi (L.) Desf. and Lycium arabicum Schweinf. (Kassas, 1956; White, 1983). Dracaena ombet occurs in plant communities of Dracaeno-Euphorbietalia abyssinicae Knapp 1968 (Deil \& Müller-Hohenstein, 1984) which are situated below the evergreen scrub zone where there are thermo-sclerophyllous species such as Maytenus senegalensis (Lam.) Exell and Euclea schimperi (DG.) Dandu, and widespread species such as Euphorbia abyssinica, Acacia etbaica and A. tortilis (Kassas, 1956). Annual average rainfall of these zones is $200 \mathrm{~mm}$.

Dracaena schizantha grows on escarpments along the northern mountains of Somalia. It is found in transition plant communities, which are situated between afromontane forests and evergreen sclerophyllous scrubs. In these transition plant communities the following species are found: Olea europaea subsp. africana (including $O$. chrysophylla and O. somaliensis Baker), Juniperus procera Hochst. ex Endl., Acokanthera schimperi Oliver, Pistacia aethiopica Kokwaro, (P. lentiscus L. subsp. emarginata Engl.), P. falcata Mart., Osyris lanceolata Hochst. \& Steud. ex DC., Euphorbia abyssinica, Monotheca buxifolia DC. (Sideroxylon gillettii Hutch. \& E.A. Bruce), Maytenus undata (Tunb.) Blakelock, etc. (Fici, 1991; Friis, 1992). Annual average rainfall reaches $500 \mathrm{~mm}$.

Dracaena serrulata is a very rare species which is found in the xerophile zone, in an area where Acacia-Commiphora bushland is dominant. This zone is situated either below the deciduous forest of Acacia or forms a mosaic with bushes of Olea europaea subsp. africana and Juniperus procera. This dragon tree occurs in the Red Sea and Aden Gulf mountains of the Arabian Peninsula. Populations are located on seafacing slopes and on inner regions of these mountains. In the xerophile zone are found several species of Acacia and Commiphora: A. niotica (L.) Willd. ex Del., A. etbaica, A. gerrardii Benth., A. tortilis, etc.; C. habessinica (Berg) Engl., C. foliaceae Sprague, C. gileadensis C. Chr., etc. Other species include Maerua crassifolia Forssk., Ziziphus spinachristi, Euphorbia balsamifera Aiton subsp. adenensis (Delf) Bally, E. cuneata Vahl, E. triaculeata Forssk., etc. (Miller \& Cope, 1996). Average annual rainfall is approximately $200 \mathrm{~mm}$. 
Dracaena cinnabari is found on slopes of the highlands of northeastern Socotra. This area is mainly covered by thickets of Rhus thyrsiffora Balf. f., Cephalocroton socotranus Balf. and Allophyllus rhoidiphyllus Balf. f. Other species present are Boswellia ameero Balf. f., B. socotrana Balf. f., Fatropha unicostata Balf. f. and Croton socotranus Balf. f. At higher altitude, this type of thicket is intermixed with Hypericum shrubland. All the plant communities are under the influence of the northeastern humid monsoons (White, 1983; Beyhl, 1995; Miller \& Cope, 1996). Mean average rainfall is approximately $400 \mathrm{~mm}$.

Byström (1960) suggested that all the dragon tree species share similar ecological requirements. They tend to grow in areas with average temperatures of $18-20^{\circ} \mathrm{C}$. They are found between $10^{\circ} \mathrm{N}$ in Somalia and $33^{\circ} \mathrm{N}$ in Madeira, and there is a clear correlation between latitude and altitude. The populations of Madeira may be found at sea-level whilst those of Somalia never occur below 1400-1800 m.

In general, all these arborescent species with an umbrella-shaped canopy are found mainly on the margins of the tropical-subtropical regions. They are part of a thermo-sclerophyllous vegetation similar to the Canarian Oleo-Rhamnetalia crenulatae or to the Arabian communities of Acacia-Commiphora. These plant communities are usually intermixed with xerophilous formations which are similar to the Canarian Kleinio-Euphorbietalia. They are mostly linked to steep and rocky landscapes, but there are some ecological differences between them.

Dracaena tamaranae grows in more xeric and hotter areas than $D$. draco. Populations of the latter tend to be affected by the northeastern trade winds and also grow under more humid conditions. The most xeric species of warm environments are $D$. serrulata and $D$. ombet. In contrast, $D$. cinnabari is the most mesophilic species. It grows along a belt of the highlands of Socotra which has the highest levels of rainfall. This habitat has similar features to those found in the region where $D$. draco is located in Macaronesia and Morocco.

\section{BIOGEOGRAPHIC RELATIONSHIPS}

Balfour (1883) and Christ (1885) have previously suggested close taxonomic relationships between the members of the dragon tree group. Other authors use this group as one of the best examples of biogeographic disjunction between Macaronesia and East Africa (Meusel, 1965; Sunding, 1970, 1979; Bramwell, 1986). Hooker (1878) was the first to propose that the dragon tree, together with other species of the Macaronesian laurel forest, are relicts of an old vegetation which once existed in northwest Africa. Axelrod (1975) is in agreement with this idea, and proposed that subtropical elements, such as Dracaena and Sideroxylon, found refuge in East and West Africa, as a consequence of the desertification of the Sahara in the late Oligocene.

\section{Dracaena and the Rand Flora}

The flora which existed in the southwestern region of South Africa during the Palaeocene was defined by Lebrun as the Rand Flora (cf. Quézel, 1978; Quézel \& Barbéro, 1993). According to Quézel $(1978,1983)$ some of the elements which 
currently thrive in northern Africa might be considered part of this ancient flora. These elements include species of the following genera: Aristida, Amphinomia, Andrachne, Gaillonia, Periploca, Tribulus, Trichodesma, Zygophyllum, Asthenaterum, Oropetium, Enneapogon, Coccullus, Neurada, Ifloga, Oligomeris, etc. Some of the xerophilous taxa which currently exist in Macaronesia, the Red Sea region and the Saharan highlands have been assigned to this flora (Quézel, 1978, 1983). These xerophilous taxa include Euphorbia balsamifera, and several species of genera such as: Euphorbia of the cactiform types, Acacia, Ceropegia, Commelina, Dracaena, Kalanchoe, Kleinia, Mesembryanthemum, Pentzia, Wahlenbergia, etc.

Quézel $(1978,1983)$ reviewed the most important biogeographical components of the North African region, and he considered $D$. draco as one of the elements of the Rand Flora. However, Quézel (1978) proposed that the East African D. ombet is linked to another floristic group associated with "tropical elements of mountain massifs next to coast". In addition, most recently Bramwell (1986, 1990) included all the species of the dragon tree group among the elements of the Rand Flora.

Quézel (1978) suggested that many of the elements of the Rand Flora reached the Sahara region using the East Africa mountains as a dispersal route during the Oligo-Miocene, and this is the reason why there are several present disjunctions between northern and southern Africa. During this process there was an intermixing with northern elements. It is well known that there have been many climatic fluctuations in northern Africa since the late Oligocene, and these major climatic changes had a drastic effect on the vegetation of this region (Aubréville, 1970, 1976; Axelrod, 1973; Quézel \& Barbéro, 1993), and, therefore, the fact that the flora of this region has several components should be borne in mind. Some of these components originated on the shores of the African Tethys which had a tropical flora similar to that found today in the Congo-Guinea region. Other North African elements are related to the laurasian subtropical flora, whereas some groups come from the dry tropical flora of the Sahara (Axelrod, 1975; Aubréville, 1976). There is no doubt that some of the North African species are linked to the Rand Flora; however, we believe that the most primitive species of the dragon tree group may have been derived from any of these flora. Fossil evidence could provide new insights into this issue.

\section{The fossil data}

None of the Tertiary Sahara fossils found so far belong to any of the Rand Flora groups (Maley, 1980). However, there are at least six species of Dracaena (Dracaenites) from remains of the French Eocene and Neogene (Saporta, 1862, 1865, 1873a,b, 1888, 1889). Three of them are considered as members of the dragon tree group (i.e. D. brongniartii, D. narbonensis and D. sepultus). One of the other three fossil species, $D$. resurgens Saporta, has been proposed to be closely related to the shrubby $D$. angustifolia Roxb. (Saporta, 1889), a species of the xerophytic group (Engler, 1908; Mies, 1995). It seems feasible from the morphology of the two remaining fossil species (D. minor Saporta and D. pusillus Saporta) that they may be also associated with the xerophytic group. However, these two fossil species are dwarf and have very long, narrow leaves.

Two additional extinct Dracaena species have been identified based on pollen from the Neogene (Van Campo \& Sivak, 1976). Pollen of the first species, D. saportae Van 
Campo \& Sivak comes from Bohemia whilst the second one, D. guinetii Van Campo \& Sivak, was found in Tunez. These two species seem to be related to those which are currently found in the Guinea-Congo region. Dracaena saportae appears to be related to Dracaena ovata Ker Gawl. whilst D. guinetii is associated with D. humilis Baker (Van Campo \& Sivak, 1976).

From these palaeobotanical data it is obvious that the only fossils which seem referable to the dragon tree group come from the Eocene-Neogene European Tethyan area. These fossils have been found together with other elements of the subtropical laurasian forest which existed in southern Europe during the Tertiary. These are related to some of the taxa which currently thrive in the Macaronesian laurel forest (Saporta, 1862, 1865, 1873b, 1889; Depape, 1922; Andreánszky, 1968; Takhtajan, 1969; Sunding, 1970, 1979; Bramwell, 1972, 1976; Axelrod, 1975). The only fossil available from the African Tethyan is clearly related to Dracaena taxa which currently grow in tropical Africa. We are aware that the Dracaena fossil data do represent a limited sample of all the taxa which existed in the past. However, palaeobotanical data suggest that at least seven Dracaena species existed in European Tethyan and also indicate that the genus Dracaena had an important centre of diversity in this region.

\section{Panbiogeographic interpretation}

A biogeographic interpretation of the patterns of distribution of the dragon tree group can be made using the panbiogeographic approach (Croizat, 1958, 1968). According to this methodology, and using both data from living and fossil species, we can establish a route which links Macaronesia with East Africa and Arabia through the European Tethyan (Fig. 6). It is worth mentioning that Croizat (1968) previously found a similar route for Sedum sect. Afrosdeum and sect. Epeteium (Crassulaceae), which runs from Macaronesia-northwest Africa to Mesopotamia, Ethiopia and Kenya. A similar situation might be found with Aeonium (Crassulaceae: Sempervivoideae) which occurs in Macaronesia, northwestern Africa and in the Red Sea region. This genus does not have any species or fossil data from the Mediterranean region, and it has been proposed as one of the Rand Flora elements by Bramwell (1986). However, an inclusive study of Aeonium and Sempervivum (Sempervivoideae) supports that both genera have a Tethyan subtropical origin (Meusel, 1965). This is in agreement with recent molecular data which suggest that the tribe Sempervivoideae is nested within the tribe Sedoideae and Sedum (Hart, 1991; van Ham, 1995; Mes, 1995; Stevens, 1995). Bearing in mind the hypothesis of an holartic origin for Sedum (Croizat, 1968; Hart \& Eggli, 1995), it seems likely that Aeonium would also have an origin in this region. This hypothesis had already been proposed by Fici (1991) who considered that this genus migrated towards southern latitudes during the Quaternary cool periods. Other examples which seem to follow similar routes are Lavandula and Coris monspeliensis L. (Fici, 1991). The data presented in this paper indicate that Dracaena and Aeonium may have similar dispersal routes (cf. Meusel, 1965). These two genera seem to have an origin in a thermo-sclerophyllous flora which existed in the Tethyan, and they do not seem to be associated with the South African eremitic-xerophile Rand Flora.

Our study gives support to the hypothesis that the current species of the dragon tree group are a depleted and relict representation of the Mio-Pliocene Saharan 


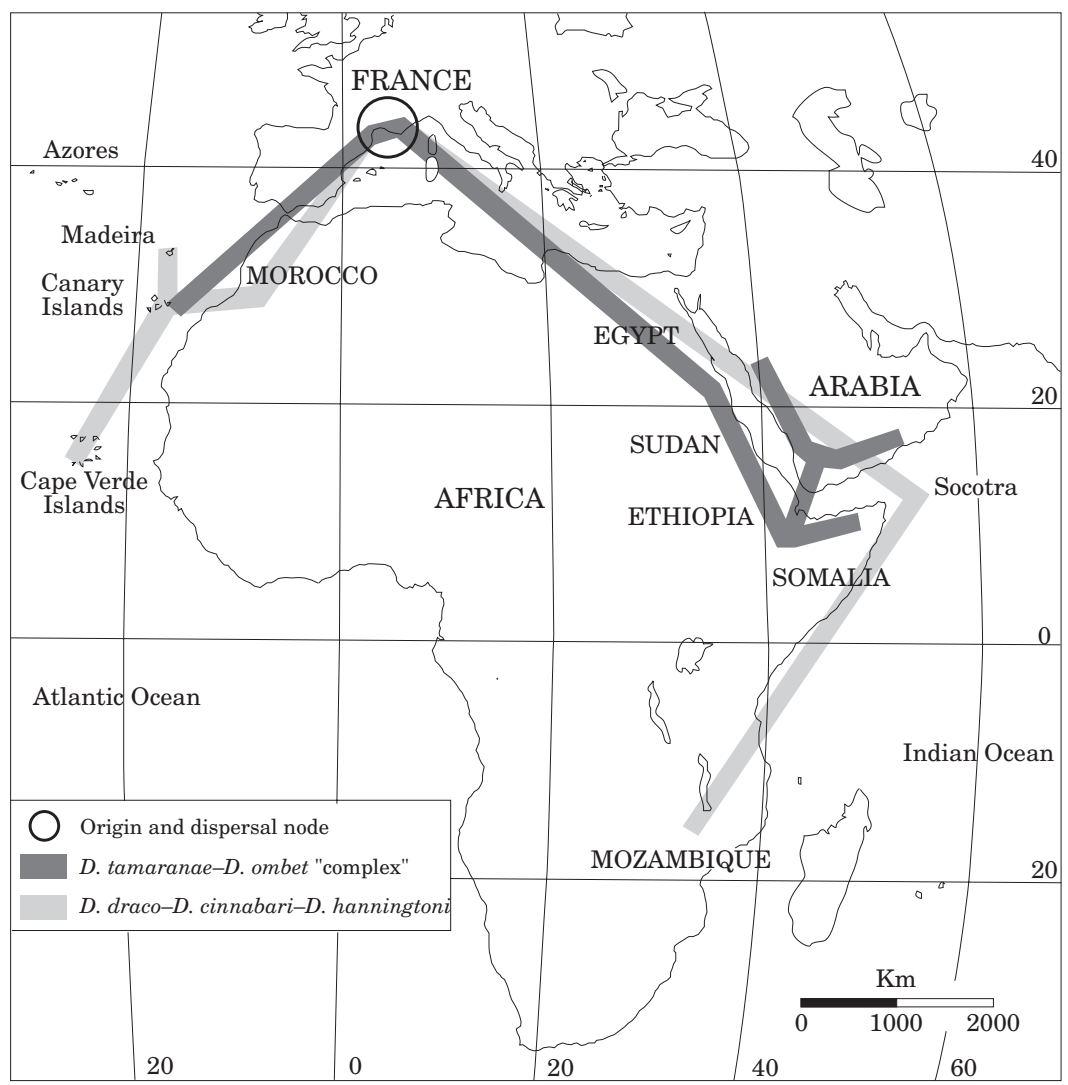

Figure 6. The two routes which link the distribution of the living and fossil species of the dragon tree group.

xerophile-sclerophyllous flora. These species would have their origin in the most thermic elements of the Oligo-Miocene laurasian subtropical flora. They existed in the edges of the forests and it is likely that they occurred on sunny and exposed areas of rocky slopes, cliffs and escarpments. Following the major climatic changes of the Miocene, they might have migrated southward where they established new populations in northern Africa. Further climatic changes might have led to the gradual disjunction of these populations towards the eastern and western margins of Africa and towards the Saharan islands mountains.

Aubréville (1976) cites Bombax as a good example of a laurasian group which could have migrated towards Africa in the Tertiary. This genus with eight species is currently restricted to tropical regions of Asia (Indo-Malaysia) and Africa. There is strong palaeobotanical evidence for the existence of Bombax in the Sahara region (Bombacoxylon) and Europe (Aubréville, 1970, 1976; Saporta, 1862, 1873b). This seems to indicate that the current African species come from an original Saharan pool which previously had a Tethyan European laurasian origin (Aubréville, 1976).

Many of the biogeographical studies of Macaronesia and North Africa have suggested that most of the xerophilous elements of these regions originated from the Rand Flora (Quézel, 1978, 1983; Maley, 1980; Bramwell, 1986, 1990; Quézel 
\& Barbéro, 1993). This view has meant that there has been a trend to postulate strong biogeographic relationships between North Africa-Macaronesia and an ancient flora which originated in southern Africa in the Palaeocene. This idea has led workers to underestimate the contribution of the thermo-sclerophyllous Tethyan flora. It might well be that Dracaena provides an example of this underestimation, which could also apply to other plant groups.

\section{ACKNOWLEDGEMENTS}

We are grateful to Trinidad Arcos (Departamento de Filología Española, Clásica y Arabe, Universidad de Las Palmas de Gran Canaria) for her invaluable help with the Latin diagnosis. We would also like to express our gratitude to Jorge Naranjo (Viceconsejería de Medio Ambiente del Gobierno de Canarias) for his help in translating the German references. J. Francisco-Ortega and D. Bramwell critically read the manuscript and provided many constructive comments. Logistic help reaching populations in the wild was provided by Antonio Quintana. This work could not have been undertaken without the help of S. Owens, P. Wilkin and J. Lowley (Royal Botanic Gardens, Kew) and the staff (particularly S. Blackmore, R. Vickery and S. Knapp) of the libraries and herbarium of the Natural History Museum of London. The Cabildo Insular de Gran Canaria provided financial support for travel to England to complete this study.

\section{REFERENCES}

Andreánszky G. 1968. Neue und interessante tertiäre Pflanzenarten aus Ungarn, VI. Acta Botanica Academiae Scientiarum Hungaricae 14(3-4): 219-242.

Andrews FW. 1956. The Flowering Plants of the Sudan. Vol. III (Compositae-Gramineae). Arbroath: T. Buncle \& Co.

Araña V, Garracedo JC. 1978. Los volcanes de las islas Canarias I: Tenerife. Madrid: Rueda.

Araña V, Ortiz R. 1984. Volcanologıa. Madrid: CSIC \& Rueda.

Aubréville A. 1970. La flore tropicale tertiaire du Sahara. Adansonia, ser. 2, 10(1): 9-14.

Aubréville A. 1976. Centres tertiaires d'origine, radiations et migrations des flores angiospermiques tropicales. Adansonia, ser. 2, 16(3): 297-354.

Axelrod DI. 1973. History of the Mediterranean Ecosystem in California. In: Di Castri F, Mooney HA, eds. Mediterranean Type Ecosystems, Origin and Structure. New York: Springer-Verlag, 225-277.

Axelrod DI. 1975. Evolution and biogeography of Madrean-Tethyan sclerophyll vegetation. Annals of the Missouri Botanical Garden 62: 280-334.

Baker JG. 1877. Dracaena schizantha Baker sp. nov. In: Trimen H, The Fournal of Botany, new series, vol. VI. London: Ranken \& Co., 71.

Baker JG. 1894. Botany of the Hadramaut expedition. Bulletin of Miscellaneous Information, Royal Botanical Garden, Kew: 342.

Baker JG. 1897. Dracaena ombet Kotschy et Peir. In: Thiselton-Dyer WT, ed. Hooker's Icones Plantarum, ser. 4, vol. VI, part. II. London: Dulay \& Co., plate 2539.

Baker JG. 1898. Liliaceae: Dracaena. In: Thiselton-Dyer WT, ed. Flora of Tropical Africa, vol. II, Hydrocharideae to Liliaceae. Ashford, Kent: L. Reeve \& Co., 436-450.

Balfour B. 1883. The Dragon's Blood Tree of Socotra (Dracaena cinnabari Balf. fil.). Transactions of the Royal Society of Edinburgh 30: 619-623.

Balfour B. 1888. Botany of Socotra. Transactions of the Royal Society of Edinburgh 31: 1-446.

Benabid A, Guzin F. 1997. Populations de dragonnier (Dracaena draco L. subsp. ajgal Benabid et 
Cuzin) au Maroc: valeurs taxonomique, biogéographique et phytosociologique. Comptes Rendus de l'Académie des Sciences, Paris, Sciences de la vie 320: 267-277.

Bentham G, Hooker JD. 1880. Genera Plantarum, III (1). London: Reeve \& Co., Williams \& Norgate.

Beyhl FE. 1995. Der Drachenbaum und seine Verwandtschaft: II. Der Echte Drachenbaum, Dracaena cinnabari, von der Insel Sokotra. Der Palmengarten 59(2): 140-145.

Bos JJ. 1984. Dracaena in West Africa. Agricultural University Wageningen Papers 84(1): v $+1-126$.

Bramwell D. 1972. Endemism in the Flora of the Canary Islands. In: Valentine DH, ed. Taxonomy, Phytogeography and Evolution. London: Academic Press, 141-159.

Bramwell D. 1976. The endemic flora of the Canary Islands. In: Kunkel G, ed. Biogeography and Ecology in the Canary Islands. The Hague: Dr W Junk bv Publishers, 207-240.

Bramwell D. 1986. Contribución a la biogeografía de las islas Canarias. Botánica Macaronésica 14: 3-34.

Bramwell D. 1990. Panbiogeography of the Canary Islands flora. In: International Symposium on Biogeographical Aspects of Insularity. Roma: Accademia Nazionale dei Lincei, 157-166.

Brown NE. 1914. Notes on the genera Cordyline, Dracaena, Pleomele, Sansevieria and Taetsia. Bulletin of Miscellaneous Information, Royal Botanic Gardens, Kew: 273-279.

Byström K. 1960. Dracaena draco L. in the Cape Verde Islands. Acta Horti-Gotoburgensis 23: 179-214.

Garracedo JC. 1984. Origen de las islas. In: Concepción A, ed. Geografia de Canarias. Santa Cruz de Tenerife: Editorial Interinsular Canaria, 55-64.

Christ DH. 1885. Vegetation und Flora der Canarischen Inseln. Botanische Fahrbücher 6: 458-526.

Gollenette S. 1985. An Illustrated Guide to the Flowers of Saudi Arabia. London: Scorpion Publishing.

Groizat L. 1958. Panbiogeography or an Introductory Synthesis of Zoogeography, Phytogeography, and Geology, vols I-II. Caracas: L Croizat.

Groizat L. 1968. Introduction raisonnée à la Biogéographie de l'Afrique. Coimbra: Memórias da Sociedade Broteriana, XX.

Deil U. 1988. Primäre und sekundäre Standorte sukkulentenreicher Pflanzengesellschaften in SüdwestArabien. Flora 180: 41-57.

Deil U, Müller-Hohenstein K. 1984. Fragmenta Phytosociologica Arabiae-Felicis I. Eine Euphorbia balsamifera Gesellschaft aus dem jemenitischen Hochland und ihre Beziehungen zu makaronesischen Pflazengesellschaften. Flora 175: 407-426.

Depage G. 1922. Recherches sur la flore Pliocene de la Vallée du Rhône. Annales des Sciences Naturelles, Botanique 10(4): 73-265.

Engler A. 1908. Die Pflanzenwelt Afrikas. In: Engler A, Drude O, eds. Die Vegetation der Erde, 9(2). Leipzig: Verlag von Wilhelm Engelmann.

Fici S. 1991. Floristic relations between eastern Africa and the Mediterranean region with special references to northern Somalia. Flora Mediterranea 1: 175-185.

Friis I. 1992. Forests and Forest Trees of Northeast Tropical Africa. New Bulletin Addition Series XV. London: HMSO, Royal Botanic Gardens, Kew.

Fuertes-Aguilar J, Ray MF, Francisco-Ortega J, Jansen RK. 1996. Systematics and evolutions of the Macaronesian endemic Malvaceae based on morphological and molecular evidence. In: Abstracts II Symposium "Fauna and Flora of the Atlantic Islands". Las Palmas de Gran Canaria, 51.

Ham RGHJ van. 1995. Phylogenetic relationships in the Crassulaceae inferred from chloroplast DNA variation. In: Hart H, Eggli U, eds. Evolution and Systematics of the Crassulaceae. Leiden: Backhuys Publishers, 16-29.

Hart H. 1991. Evolution and classification of the European Sedum species (Crassulaceae). Flora Mediterranea 1: 31-61.

Hart H, Eggli U. 1995. Introduction: Evolution of Crassulaceae systematics. In: Hart H, Eggli U, eds. Evolution and Systematics of the Crassulaceae. Leiden: Backhuys Publishers, 7-15.

Hooker JD. 1878. On the Canarian Flora as compared with the Maroccan. In: Hooker JD, Ball J, eds. Fournal of a Tour in Marocco and the Great Atlas. London: Macmillan and Co., 404-421.

Hooker WJ, Smith J. 1851. Dracaena draco. Dragon's-blood Tree. Botanical Magazine 77: tab. 4571.

IUCN Species Survival Commission. 1994. IUCN Red List Categories. Gland: IUCN.

Kassas M. 1956. The mist Oasis of Erkwit, Sudan. Fournal of Ecology 49: 180-194.

Kunkel G. 1972. Sobre el hallazgo del drago (Dracaena draco) en Gran Canaria. Cuadernos de Botánica Canaria 14-15: 39-42.

Kunkel G. 1973. Novedades en la flora de las islas orientales, con una nota sobre Dracaena draco en Gran Canaria. Cuadernos de Botánica Canaria 17: 35-37. 
Linnaeus G. 1767. Systema Natura, ed. 12, 2. Holmiae: Impensis Direct, 736 pp.

Mabberley DJ. 1990. The Plant-Book. A portable dictionary of the higher plants. Cambridge: Cambridge University Press.

Maire R. 1958. Flore de l'Afrique du Nord, vol. 5: Monocotyledonae: Liliales: Liliaceae. Paris: Paul Lechevalier.

Maley J. 1980. Les changements climatiques de la fin du Tertiaire en Afrique: leur conséquence sur l'apparition du Sahara et de sa végétation. In: Williams MAJ, Faure H, eds. The Sahara and the Nile. Quaternary environments and prehistoric occupation in northern Africa. Rotterdam: AA Balkema, 63-86.

Marrero A, González-Artiles F, González-Martín M. 1995. Corología de varias especies raras de las bandas del sur de Gran Canaria, islas Canarias. In: Notas corológico-taxonómicas de la Flora Macaronésica $\left(\mathrm{n}^{\text {os }}\right.$ 35-81). Botánica Macaronésica 33: 49-63.

Mes THM. 1995. Phylogenetic and systematic implications of chloroplast and nuclear spacer sequence variation in the Macaronesian Sempervivoideae and related Sedoideae. In: Hart H, Eggli U, eds. Evolution and Systematics of the Crassulaceae. Leiden: Backhuys Publishers, 30-44.

Meusel H. 1965. Die Reliktvegetation der Kanarischen Inseln in ihren Beziehungen zur süd- und mitteleuropäischen Flora. In: Gersch M, ed. Gesammelte Vorträge über moderne Probleme der Abstammunslehre, 1. Jena: Friedrich-Schiller-Universität, 117-136.

Mies B. 1995. On the comparison of the flora and vegetation of the island groups of Socotra and Macaronesia. Boletim do Museu Municipal do Funchal (História Natural), sup. 4(B): 455-471.

Miller AG, Cope TA. 1996. Flore of the Arabian Peninsula and Socotra, vol. 1. Edinburgh: Edinburgh University Press, Royal Botanic Garden, Edinburgh and Royal Botanic Gardens, Kew.

Quézel P. 1978. Analysis of the flora of Mediterranean and Saharan Africa. Annals of the Missouri Botanical Garden 65: 479-534.

Quézel P. 1983. Flore et végétation actuelles de l'Africa du nord, leur signification en fonction de l'origine, de l'évolution et des migrations des flores et structures de végétation passées. Bothalia 14(3-4): 411-416.

Quézel P, Barbéro M. 1993. Variations climatiques au Sahara et en Afrique sèche depuis le Pliocène: enseignements de la flore et de la végétation actuelles. Bulletin d'Ecologie 24(2-3-4): 191-202.

Ray MF. 1995. Systematics of Lavatera and Malva (Malvaceae, Malveae) - a new perspective. Plant Systematics and Evolution 198: 29-53.

Rivas-Goday S, Esteve-Ghueca F. 1965. Ensayo fitosociológico de la Crassi-Euphorbietea macaronesica y estudio de los tabaibales y cardonales de Gran Canaria. Anales del Instituto Botánico Af Cavanilles 22: 221-339.

Rivas-Martínez S, Wildpret W, Del Arco M, Rodríguez O, Pérez de Paz PL, Garcia-Gallo A, Acebes JR, Díaz TE, Fernández-González F. 1993. Las comunidades vegetales de la isla de Tenerife (islas Canarias). Itinera Geobotánica 7: 169-374.

Rodrigo Pérez J, Montelongo Parada V. 1986. Distribución de especies significativas para la comprensión de las formaciones boscosas en Gran Canaria (Islas Canarias). I. Botánica Macaronésica 12-13: 3-16.

Santos A. 1983. Vegetación y flora de La Palma. Santa Cruz de Tenerife: Interinsular Canaria.

Saporta MG. 1862. Études sur la végétation du sud-est de la France a l'époque tertiaire. III. Flore des lignites inférieurs, ou étage à lignite proprement dit. Annales des Sciences Naturelles, Botanique 4(17): 191-311+14 lam.

Saporta MG. 1865. Études sur la végétation du sud-est de la France a l'époque tertiaire. $2^{a}$ partie, III, Flore d'Armissan et de Peyriac, dans le bassin de Narbonne (Aude). Annales des Sciences Naturelles, Botanique 5(4): 5-264 + 13 lam.

Saporta MG. 1873a. Études sur la végétation du sud-est de la France a l'époque tertiaire. Supplément I, Révision de la flore des gypses d'Aix. II Description des espèces. Annales des Sciences Naturalles, Botanique 5(17): 5-44.

Saporta MG. 1873b. Études sur la végétation du sud-est de la France a l'époque tertiaire. Révision de la flore des gypses d'Aix. Supplément I. Dicotyledoneae. Annales des Sciences Naturelles, Botanique 5(18): 23-146+ 18 lam.

Saporta MG. 1888. Dernières adjonctions a la Flore fossile d'Aix-en-Provence. Description des espèces $-1^{a}$ partie. Annales des Sciences Naturelles, Botanique 7(7): 1-104.

Saporta MG. 1889. Dernières adjonctions a la Flore fossile d'Aix-en-Provence. Description des espèces - $2^{a}$ partie. Annales des Sciences Naturelles, Botanique 7(10): 1-192+30 lam.

Schweinfurth G. 1868. Vegetationsskizzen aus dem südnubischen Küstengebirge. Botanische Zeitung 50: $849-860$. 
Stevens JF. 1995. Chemotaxonomy of the Eurasian Sedoideae and Sempervivoideae. In: Hart H, Eggli U, eds. Evolution and Systematics of the Crassulaceae. Leiden: Backhuys Publishers, 45-75.

Sunding P. 1970. Elementer i Kanariøyenes flora, og teorier til forklaring av floraens opprinnelse. Blyttia 28: 229-256.

Sunding P. 1979. Origins of the Macaronesian flora. In: Bramwell D, ed. Plants and Islands. London: Academic Press, 13-40.

Täckholm V, Drar M. 1973. Flora of Egypt (2nd edn), vol. III: Angiospermae, part Monocotyledones: Liliaceae-Musaceae. Koenigstein: Otto Koeltz Antiquariat.

Takhtajan A. 1969. Flowering Plants. Origin and dispersal. Edinburgh: Oliver \& Boyd.

Thonner FR. 1962. The flowering plants of Africa. In: Cramer J, Swann HK, eds. Historiae Naturalis Classica. XXVII. New York: Wheldon \& Wesley, Ltd and Hafner Publishing Co.

Thulin M. 1995. Dracaenaceae. In: Thulin M, ed. Flora of Somalia, vol. 4: 146. Kew: Royal Botanic Grdens, 27-30, plate 1-E.

Turland NJ. 1995. Agavaceae. In: Press JR, Short MJ, eds. Flora of Madeira. London: HMSO, Natural History Museum, 391-392.

Van Campo E, Sivak J. 1976. Présence de pollens de Dracaena dans le Néogène méditerranéen. Revue de Micropaléontologie 18(4): 264-268.

Webb PB, Berthelot S. 1836-50. Histoire Naturelle des Iles Canaries. III Botanique. 2 Phytographia Canariensis. Paris.

Wendel JF, Percival AE. 1990. Molecular divergence in the Galapagos Islands - Baja California species pair, Gossypium klotzschianum and G. davidsonii (Malvaceae). Plant Systematics and Evolutions 171: 99-115.

Wendel JF, Percy RG. 1990. Allozyme diversity and introgression in the Galapagos Islands endemic Gossypium darwinii and its relationship to continental G. barbadense. Biochemical Systematics and Ecology 18(7/8): 517-528.

White F. 1983. The Vegetation of Africa. A descriptive memoir to accompany the Unesco/AETFA/UNSO vegetation map of Africa. Switzerland: Unesco.

APPENDIX

Plant material: Herbarium specimens

Dracaena draco (L.) L., Tenerife, Buenavista del Norte, Ravelo, leg. A. Marrero, R.S. Almeida \& M. González-Martín, 31.vii.1997 (LPA: 18504); Idem, Tenerife, Adeje, barranco del Infierno, leg. R.S. Almeida \& A. Marrero, 11.viii. 1997 (LPA: 18505); Idem, Gran Canaria, Santa Brígida, barranco Alonso, Pino Santo (sub-spontaneus), leg. A. Marrero \& R.S. Almeida, 4.viii.1997 (LPA: 18503) (inflorescence, basal bracts, leaves); Idem, Gran Canaria, Jardín Botánico Viera y Clavijo (ex horto), leg. A. Marrero, 22.vii.1997 (LPA: 18506, 18507) (inflorescence, basal bracts, leaves); Idem, (ex horto), from Cape Verde, leg. A. Marrero, 4.vii. 1997 (LPA: 18510, 18511, 18512) (seedling, inflorescence, infructescence, basal bracts, leaves); Idem, Gran Canaria, El Batán-Guiniguada (ex horto), leg. A. Marrero, 25.vii.1997 (LPA: 18508) (inflorescence, basal bracts, leaves). D. cinnabari Balf. f., Socotra, Feb.-March, 1880, comm. Prof. Bayley Balfour, Aug. 1880 (K TYPUS) (2 sheets, inflorescence, basal bracts, leaves, + Ic. Prof. Balfour 5/93); Idem. (BM TYPUS Dupl. inflorescence, basal bracts, leaves); Idem, Socotra, Dr. Balfour, April, 1880 (K) (infructescence); Idem, Ins. Socotra (Hort. Kew.), coll. Wikeham Perry, s/n, 19.ix.1878 (K) (leaves); Idem, Socotra, Jebel Shihali, Hagghiher Mts., $3500 \mathrm{ft}$., leg. A.R. Smith \& J. Lavranos, 448, 20.iv.1967 (K) (inflorescence); Idem, Socotra, Taukak village, above Hasen, 450-480 m, leg. M. Thulin \& N. Gifri, 8603, 19.i.1994 (K) (infructescence, basal bracts); Idem, Gran Canaria, Jardín Botánico Viera y Clavijo (ex horto), leg. A. Marrero, 1.ix.1997 (LPA: 18513, 18514) (leaves). D. ombet Kotschy et Peyr., Mount Erkowit, near Suakin, Schweinfurth, 250, 16.ix.1868 (K) (inflorescence, leaves + Hooker's Ic. Pl. t. 2539); Idem, Gran Canaria, Jardín Botánico Viera y Glavijo (ex horto), leg. A. Marrero, 22.viii. 1997 (LPA: 18515); Idem, 1.ix.1997 (LPA:1'8516) (leaves); D. cf. ombet, Djibouti, Wadi Dounyar, $\mathrm{S}$ of Ali Sabreh, crest of limestone ridge, $2400 \mathrm{ft}$., I.S. Collenette, 8644, 20.iv.1993 (K) (inflorescence, leaves). D. serrulata Baker, found on the hills near Dobaibah, elevation about $4000 \mathrm{ft}$. , coll. W. Lunt., 206, 26.ii.1894 (K TYPUS) (leaves); Idem, Jebel Minmar, Khawlaan as Sham, c. 2500 m, J.R.I. Wood, Y/75/624, 29.viii.1975 (BM) (2 sheets, infructescence, leaves); Idem, on the south side of Jebel Minmar (Sàdah-Sagayn), c. 2600 m, J.R.I. Wood, 624, 
29.viii.1975 (K) (infructescence); Idem, Saudi Arabia, the Asir, about $10 \mathrm{~km}$ south of Abha, I.S. Collenette, 628, 6.iv.1978 (K) (leaves); Idem, Saudi Arabia, South Hijaz, Jebel Aba Hassan, a sandstone massif about $50 \mathrm{~km}$ south of the escarpment between Abha-Najran, $5500 \mathrm{ft}$., I.S. Collenette, 1291, 6.iv.1979 (K) (inflorescence); Idem, Saudi Arabia, S-SW of Madinah, 80 km, 5000 ft. (c. 4600 m), I.S. Collenette, 3789, 15.viii.1982 (K) (infructescence); Idem, Oman, N of Jabel Qaars, road to Sarfay \& Dhofar, R.M. Lawton, 2398, 28.viii.1982 (K) (2 sheets, infructescence, basal bracts, leaves); Idem, Duplic. (BM) (infructescence, basal bracts); Idem, Oman, Dhofar, Jebel Semhan above Mirbat, $1350 \mathrm{~m}$, A.G. Miller \& J.A. Nyberg, M-9167, 7.ix.1989 (K) (infructescence, leaves). D. schizantha Baker, SomaliLand, Meid, Ahl-n. Serrusgeb, 800-1800 m, J.M. Hildebrandt, 1742, April 1875 (BM TYPUS) (inflorescence); Idem, (K Duplic.) (inflorescence); Idem, Ethiopia, Harar Prov., Steep slopes below Dangago, $15 \mathrm{~km}$ SE of Diredawa, along the road to Harar, $1700 \mathrm{~m}$, W. Burger, 1516-1516a, 24.ii.1962 (K) (3 sheets, inflorescence, leaves); Idem, Ethiopia, Harar Prov., Steep slopes below Dangago, $15 \mathrm{~km}$ SE of Diredawa, along the road to Harar, W. Burger, 3714, 4.iii.1965 (K) (2 sheets, inflorescence, leaves); Idem, Somalia, Valley sides, site A/5 Limestone Mountains, 1340 m, J.B. Billett \& R.M. Watson, 23462, 16 \& 18.vi.1981 (K) (2 sheets, infructescence, leaves); Idem, NE Somalia, environs de Galgala, G. Barbier, 962, 5.xii.1983 (K) (infructescence, basal bracts); Idem, Royal Botanical Gardens, Kew, (ex horto), leg. P. Wilkin, A. Marrero \& R.S. Almeida, 21.x.1997 (LPA: 18509) (leaves). D. hanningtoni Baker, E Trop. Africa, German East Africa, Unyamwezi, Msalala, coll. \& com. rev. J. Hannington (K TYPUS) (inflorescence). 